\title{
Process and Lessons of International Development Cooperation Through Multi Industry Cluster Project
}

\author{
Kim, Seong Hee ${ }^{1}$ and Kim, Ju Hyun ${ }^{2}$ \\ ${ }^{1,2}$ Anyang University, Korea \\ ${ }^{1}$ sean@anyang.ac.kr, ${ }^{2}$ jhkim@anyang.ac.kr
}

\begin{abstract}
The focus of this study is to examine efficient ways of promoting the project and implications in international development cooperation project with analysis of participants' organizations and roles. This study would like to share the lessons and experiences from main issues of each phases of international development cooperation project through Feasibility Study for Philippines Multi-industry Cluster Project.

The specific goals of this study are as follow.

The first, consideration on the roles of Korea and Philippine government in the process of international development cooperation project based on demands and needs of recipient country. The second, examining the strategic countermeasures for main issues in the process of cooperation between agencies; recipient country, Department of Agriculture and planning team of donor country, F/S Team. The third, reviewing the model and the project structure in order to secure the realizability of the project in planning level of implementation strategy and examining the political tasks and strategic proposals in order to attract private investments.

The implication of this study shows the model of win-win strategy for both recipient country and donor country in international development cooperation with presentation of packaged strategic approach from the establishment of regional plan to the establishment of specific plan for project area. It could be benchmarked as a successful case in international development cooperation, presenting the project model which private investment cooperation could be made in international development cooperation through the establishment of specific implementation strategy after master plan.
\end{abstract}

Key Words: international development cooperation, public private partnership, country partnership strategy, multi industry cluster, private investment cooperation

\section{Introduction}

International development cooperation has begun in earnest from the Marshall plan, the European recovery program by US, after the end of World War II. International development cooperation has consistently progressed as global public goods with a view to effectively handle and solve the issues based on poverty such as population, disease, environment, terrorism, etc. and to achieve MDGs (Millennium Development Goals) with vision of mankind for anti-poverty.

Korea was one of the poorest countries in the world but has achieved present economic success in the last half century. It is one of the few successful cases in international development cooperation. Korea, the only one case switched from recipient country to donor country, has served as a member of OECD DAC (Development Assistance Committee) since January 2010. Korea has reinforced international development cooperation in various field such as education, public health, public administration, agriculture and fisheries, industrial energy, environment, gender, ICT, human rights, climate change, etc. and will expand her ODA (Official Development Assistance) up to $0.25 \%$ of GNI by 2015 . 
Learning lessons from her own experiences of rapid economic development, Korea is establishing assistance advancing strategy for expanding role of Korea in international society. But there is a danger that this might be a unilateral aid from donor country. Therefore, there are necessities of establishing demand based CPS (Country Partnership Strategy) and promoting demand based knowledge sharing program which provides experiences of development with packaging both of them for harmonious liaison.

The securement of sustainability and realizability of development cooperation is also needed with win-win strategy for both recipient country and donor country. For example, direct investments of private enterprises would be made through Korea in recipient country's position and development of market in public private partnership and private level would be linked in donor country's position. The most important point is the cooperation of various participants in international development cooperation project.

The focus of this study is to examine efficient ways of promoting the project and implications in international development cooperation project with analysis of participants' organizations and roles. This study would like to share the lessons and experiences from main issues of each phases of international development cooperation project through Feasibility Study for Philippines Multi-industry Cluster Project.

The specific goals of this study are as follow.

The first, consideration on the roles of Korea and Philippine government in the process of international development cooperation project based on demands and needs of recipient country.

The second, examining the strategic countermeasures for main issues in the process of cooperation between agencies; recipient country, Department of Agriculture and planning team of donor country, F/S Team.

The third, reviewing the model and the project structure in order to secure the realizability of the project in planning level of implementation strategy and examining the political tasks and strategic proposals in order to attract private investments.

\section{Outline and Main Issues of Philippines MIC Project}

\subsection{Background and Objective of MIC Project}

As one of the largest agrarian countries throughout the world, agriculture in the Philippines accounts for $15 \%$ of the GDP and $1 / 3$ of the whole population are engaged in agricultural activities. This is because the country has rich natural resources and good climate conditions that create competitive agricultural environment. Notwithstanding, agricultural development is lagging behind in the global market owing to low productivity, insufficient investment, inefficient land use pattern and underdeveloped technology in agriculture-related fields such as

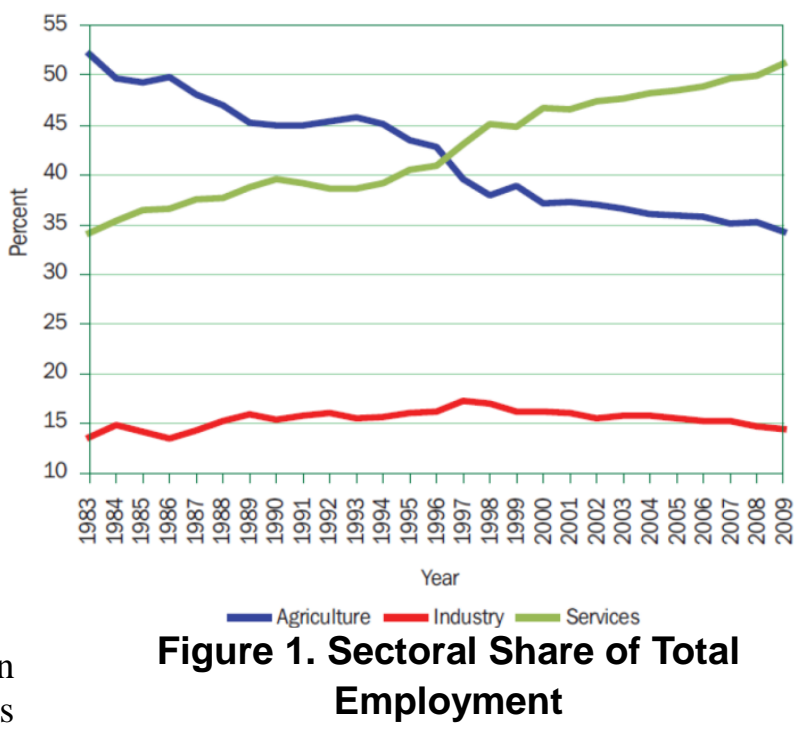
irrigation, post-harvest storage and processing, etc.

In this project, we suggested to develop Multi-industry Cluster (MIC) based on agricultural production in the Philippines, which is a good way to utilize existing 
agriculture-centered industry of the nation and effectively attract foreign investment. The MIC development can be a stimulus to increase the productivity and competitiveness of Philippines agriculture and other related industries, and to respond to the challenges that the Philippines farming villages are facing, which include unemployment, underemployment and poverty.

The MIC shall contribute to economic development including increase of rural incomes, generation of employment, promotion of food security, and alleviation of rural poverty in the Philippines through the successful implementation of the project. So, the project objective was to seek an effective model of MIC which aims to establish agro-based industries (agro-processing, agro-manufacturing, etc.), renewable energy (ethanol, biomass power, hydro and wind power, etc.,) and other eco-tourism industries considering regional industrial development potential and infrastructure conditions in the Philippines.

Especially the development of MIC was expected to be a symbol of favorable relationship between Philippines and Korea in memory of the $60^{\text {th }}$ anniversary of amity in 2009. The technology and capital of Korea and labor and resources of Philippines are in an inter-complementary relationship and will be a win-win strategy for the two countries.

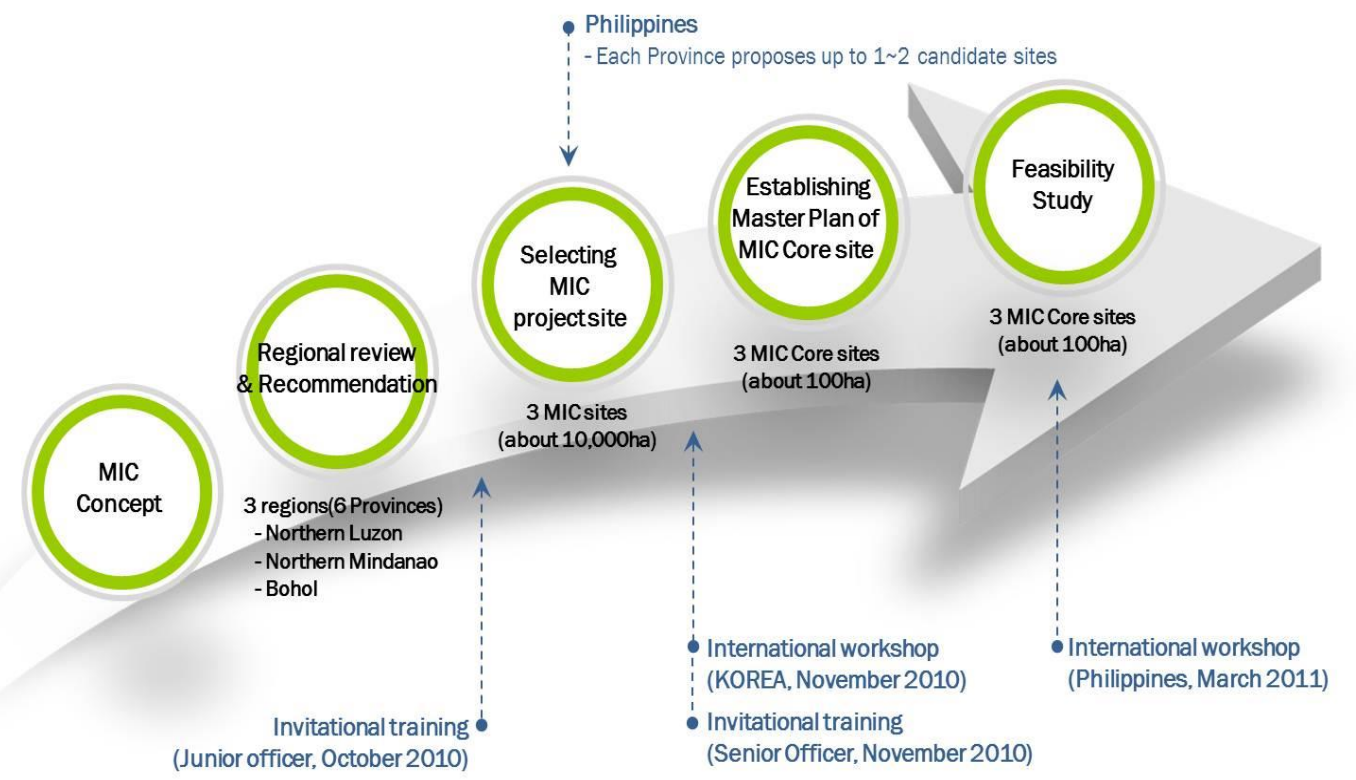

Figure 2. MIC Project Flow

\subsection{Main Issues if MIC Project}

The main issues in MIC project can be classified into three parts according to progress phase. The first issue was appropriate project selection from various international development cooperation projects in the preparation phase. The MIC project must be helpful to recipient country based on demand and needs and it must be mutually beneficial as a win-win strategy in respect of sustainable and efficient cooperation. After choice of cooperation project, the scope of MIC project should be limited and recorded as a result of discussion.

The second issue was collaborative planning with partners - Korea embassy, Korea International Cooperation Agency, F/S study team (experts group), Department of Agriculture in Philippines, local government, etc., - in the implementation phase. F/S study team set up MIC concept and makes an effort Philippines officer to understand MIC concept. And then we established regional planning based on MIC concept and seek pilot site to make MIC among several province.

The third issue was strategy making to induce investment and to push ahead with 
development in selected pilot site. Each government wants this project is not plan for plan but action program. And to conclude, MIC development is in progress after end of master plan.

\section{Process of Project Selection as a Win-Win Strategy}

The securement of sustainability and realizability of development cooperation is needed with win-win strategy for both recipient country and donor country. In a recipient country position, the government of the Philippines has long acknowledged both its imbalanced development status and potential of the country's agriculture and related industries as the growth engine. It is expected that the competitiveness of the agriculture sector would bring the increase of household income and expanded employment opportunities as well as positive impacts on related industries. In a donor country position, the government of the Korea has recognized the necessity of overseas expansion of the private enterprise and food security to respond against instability of the grain market.

Regarding this issue, the government of the Philippines made the official request to Korea International Cooperation Agency (KOICA), an organization affiliated with the Korea Ministry of Foreign Affairs and Trade, in May 2009, and two countries signed on Memorandom of Understanding (MOU) through ASEAN Summit Talk in May 2009. Followed by KOICA's site survey, 'Terms of Reference (TOR)' was prepared in 'Records of Discussion (R/D)' and signed in the Philippines on November 26, 2009.

Table 1. Project Process in Preparation Phase

\begin{tabular}{c|l}
\hline Date & \multicolumn{1}{c}{ Contents } \\
\hline May 2009 & Acceptance of official call-for document for development proposal \\
\hline May 2009 & Korea-ASEAN Summit (MOU agreement) \\
\hline Sep. 2009 & Preliminary survey by KOICA \\
\hline Nov. 2009 & KOREA-PHILIPPINES economic cooperation forum \\
\hline Nov. 2009 & Implementation discussion and R/D agreement \\
\hline Feb. 2010 & Official selection of consultant team \\
\hline
\end{tabular}

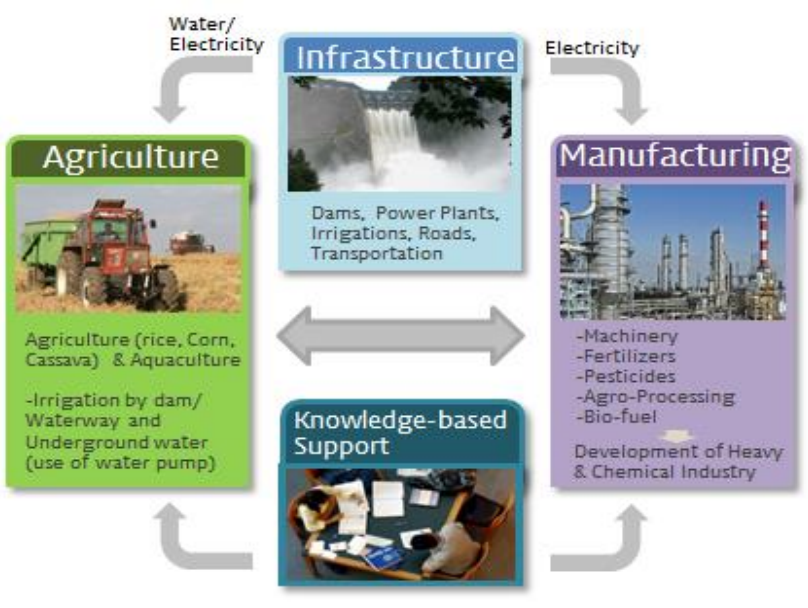

Ms. Bernadette Romulo-Puyat (Undersecretary of DA)

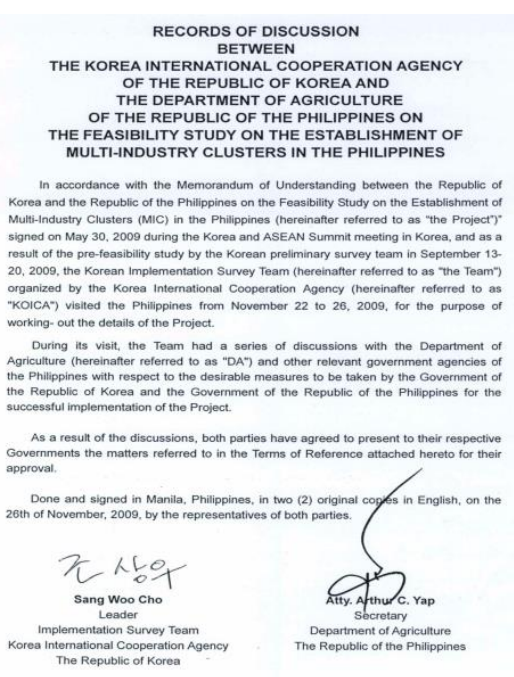

BETWEEN
A INTERNATIONAL COOPERATION AGENCY OF THE REPUBLIC OF THE PHILIPPINES ON
OHE FEASIBILITY STUDY ON THE ESTABLISHMENT OF MULTI-INDUSTRY CLUSTERS IN THE PHILIPPINES

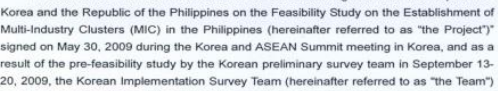

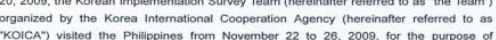

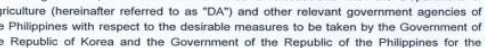
As a result of the discussions, both partios have agreed to present to their respective
covernments the matters referred to in the Terms of Referenco attached hereto for their approval.
Done and signed in Manila, Philippines, in two (2) original coofss in English, on the
28th of November, 2009, by the representattives of both parties.

(n) 
The economic cooperation forum had been held in Nov 2009 in order to boost concern for the MIC project of international development cooperation of Korea-Philippines and its efficient access. The scope of the project for realization of MIC had been adjusted through forming mutual consensus.

Although this task applies to the fundamental conception and the feasibility study which is the first step of entire MIC process, we set up the range of the project contemplating durability of economic cooperation which brings intergovernmental cooperation to substantive private sector investment by establishing a road map for the specific areas such as preliminary study including feasibility study, set up of business structure, land development construction as an execution and operation.

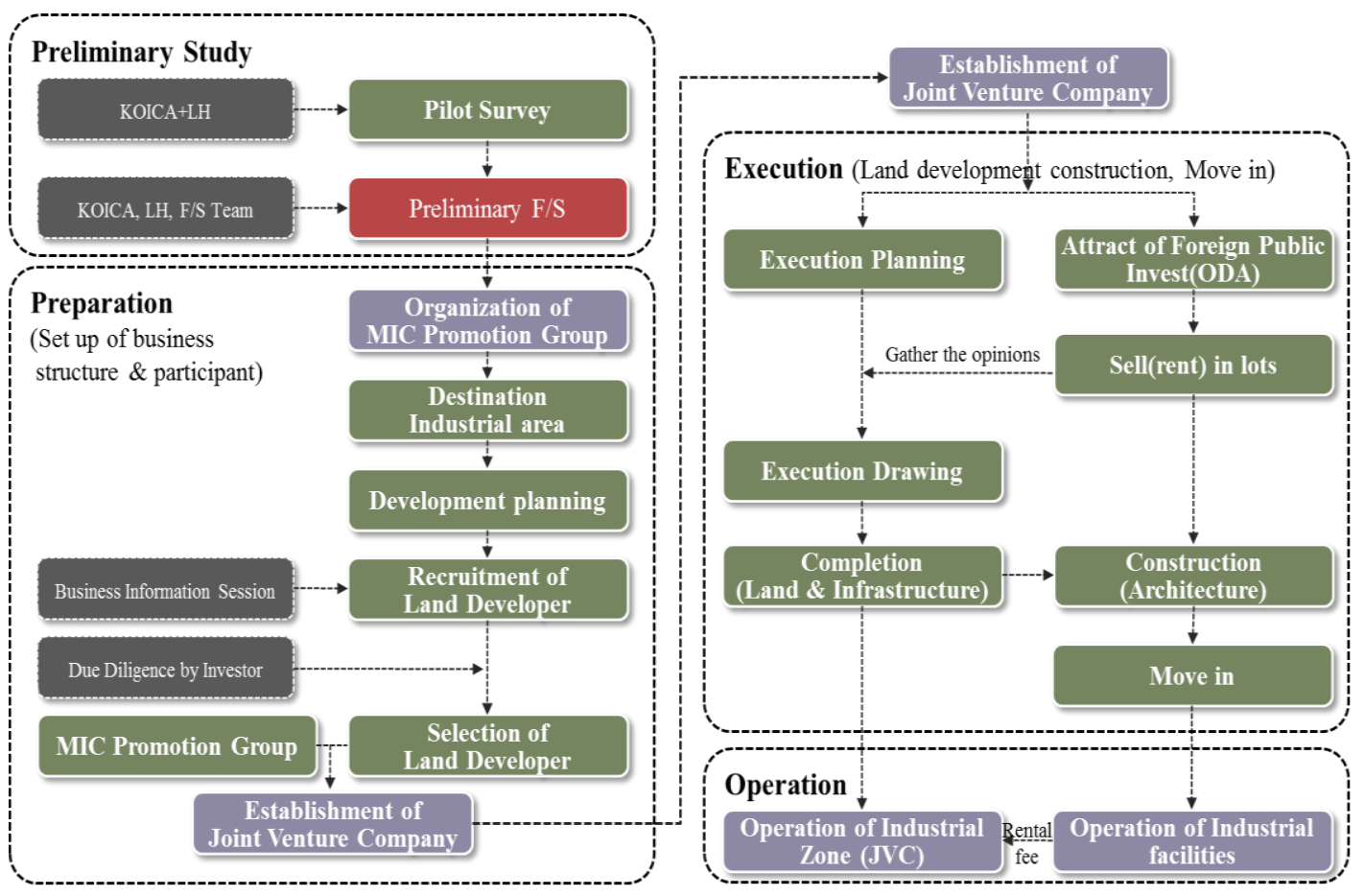

Figure 5. Recommended Successful MIC Roadmap by F/S Team

We established a regional master plan contemplating medium and long term development of the region, and drew various detailed assignments which are required for regional development. We adopted detailed scope and methodology of the task which suggests assignments for sustainable development of the region, not for one-time project, through strategic approaches which lead MIC by private sector investment as a pilot project for realization of regional master plan. This program has been so organized that Philippine government can attract grand aides and credit assistance from international organizations or Korean government and sustainable investments from private sector. This program has been reflected in medium and long term development plan of the Philippines government (MTPDP) in order to boost realization of the project.

In addition, we tried to deliver on Korean experiences to Philippine officials with training session and included the process which we attract various investment companies and promote the project to international organizations through workshops into the scope of the task. 
Table 2. Project Work Scope

\begin{tabular}{|c|c|}
\hline Item & Activities \\
\hline $\begin{array}{l}\text { Survey and } \\
\text { Evaluation }\end{array}$ & $\begin{array}{l}\text { - Detailed site survey and evaluation on the candidate sites } \\
\text { - Review of the existing document on policies, plans, laws, etc. } \\
\text { - Recommendation and determination of the best candidate site }\end{array}$ \\
\hline $\begin{array}{l}\text { Concepts Design and } \\
\text { Feasibility Study }\end{array}$ & $\begin{array}{l}\text { - Creation of the optimal development model for MIC } \\
\text { - MIC schematic development plan } \\
\text { - Development direction for related industries } \\
\text { - Public facilities development plan } \\
\text { - Presentation of future industry development } \\
\text { - Feasibility study and implementation plan } \\
\text { - Master plan for the pilot project }\end{array}$ \\
\hline $\begin{array}{l}\text { Training of Philippine } \\
\text { Officials and } \\
\text { Personnel }\end{array}$ & $\begin{array}{l}\text { - Detailed planning of training program including lectures, field } \\
\text { and case studies and seminar } \\
\text { - Training of Philippine officials and personnel in Korea }\end{array}$ \\
\hline $\begin{array}{l}\text { International } \\
\text { Workshop }\end{array}$ & $\begin{array}{l}\text { - Conduct of workshop in both Korea and the Philippines } \\
\text { - Invite officials, specialists, scholars and researchers from both } \\
\text { countries as panelists }\end{array}$ \\
\hline
\end{tabular}

\section{Process of Planning Cooperation with Partners}

All the activities had been carried out in cooperation with 'Department of Agriculture (DA)' of the government of the Philippines and related Filipino inter-agencies like below figure. So consensus building of all project participants was very important process as well as assertive cooperation.

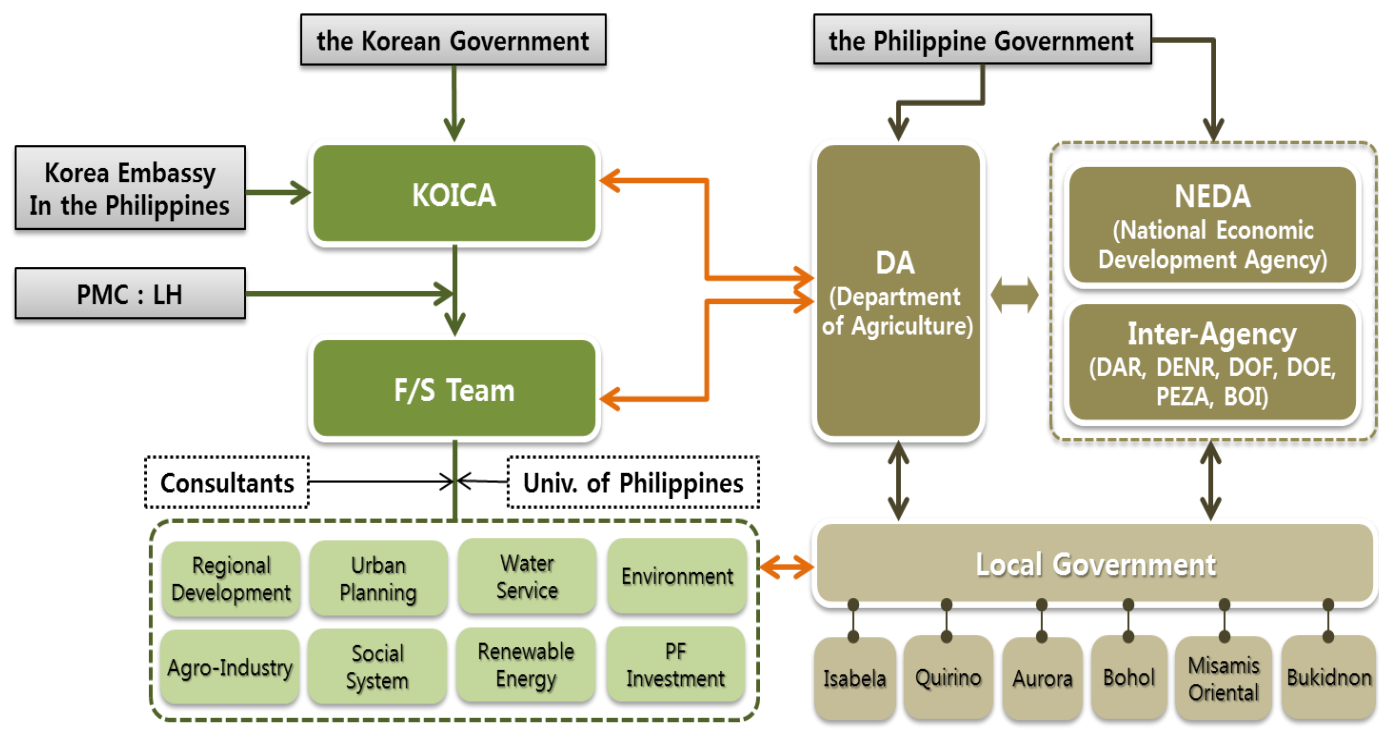

Figure 6. Participants of MIC Project

The feasibility study and concept plan project on the establishment of MIC encompassed several large processes like Figure 7. Among several processes, this study focuses on MIC concept, site evaluation \& selection, strategic plan for execution in respect of consensus building and mutual cooperation. 


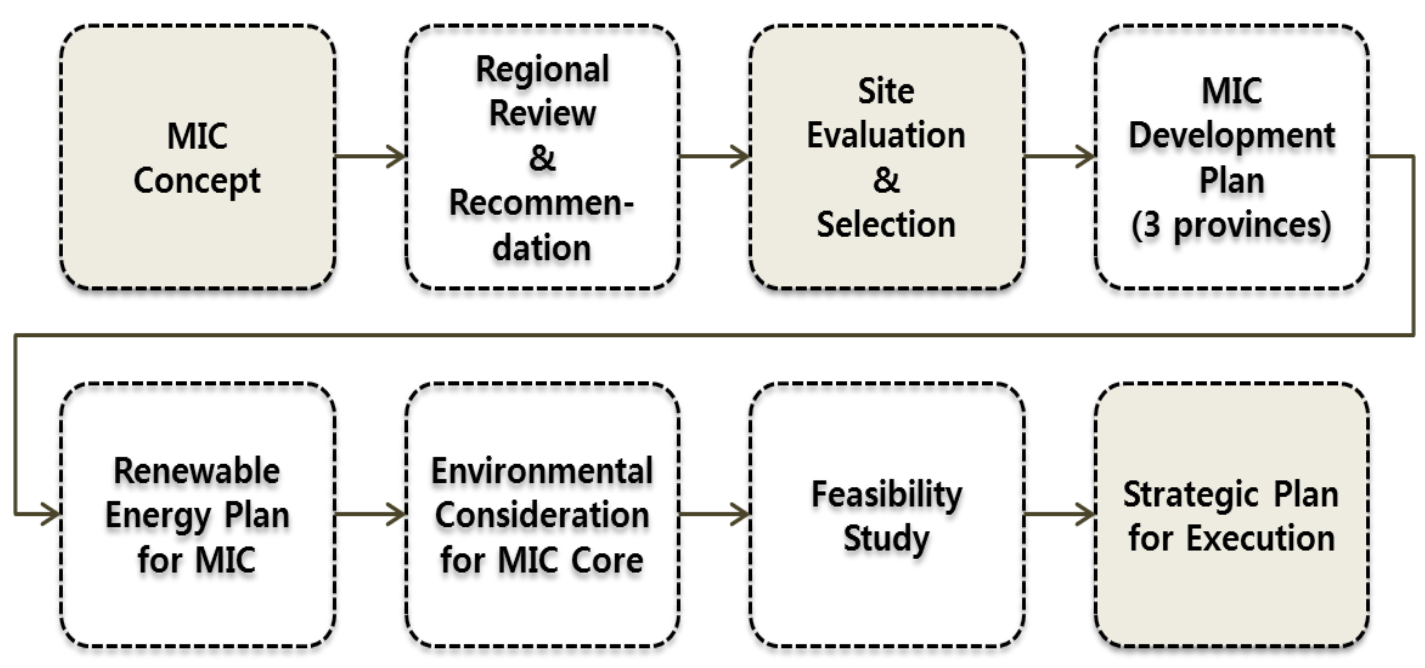

Figure 7. Process of MIC Project

\subsection{Consensus Building: Defining MIC Concept}

The first step of consensus building was defining suitable MIC concept in the Philippines situation. MIC was briefly defined economic eco system based on cluster theory and MIC shall help the farmers and industry in the surrounding area; foster the development of agriculture, agribusiness and related business network; and lead the overall growth of the region. And MIC core can be catalyst of MIC development as supportive core. MIC core, which is functioned as an industrial park, is defined as an effective measure to drive the overall growth of the industry cluster, triggering the development of agribusiness and related business network.

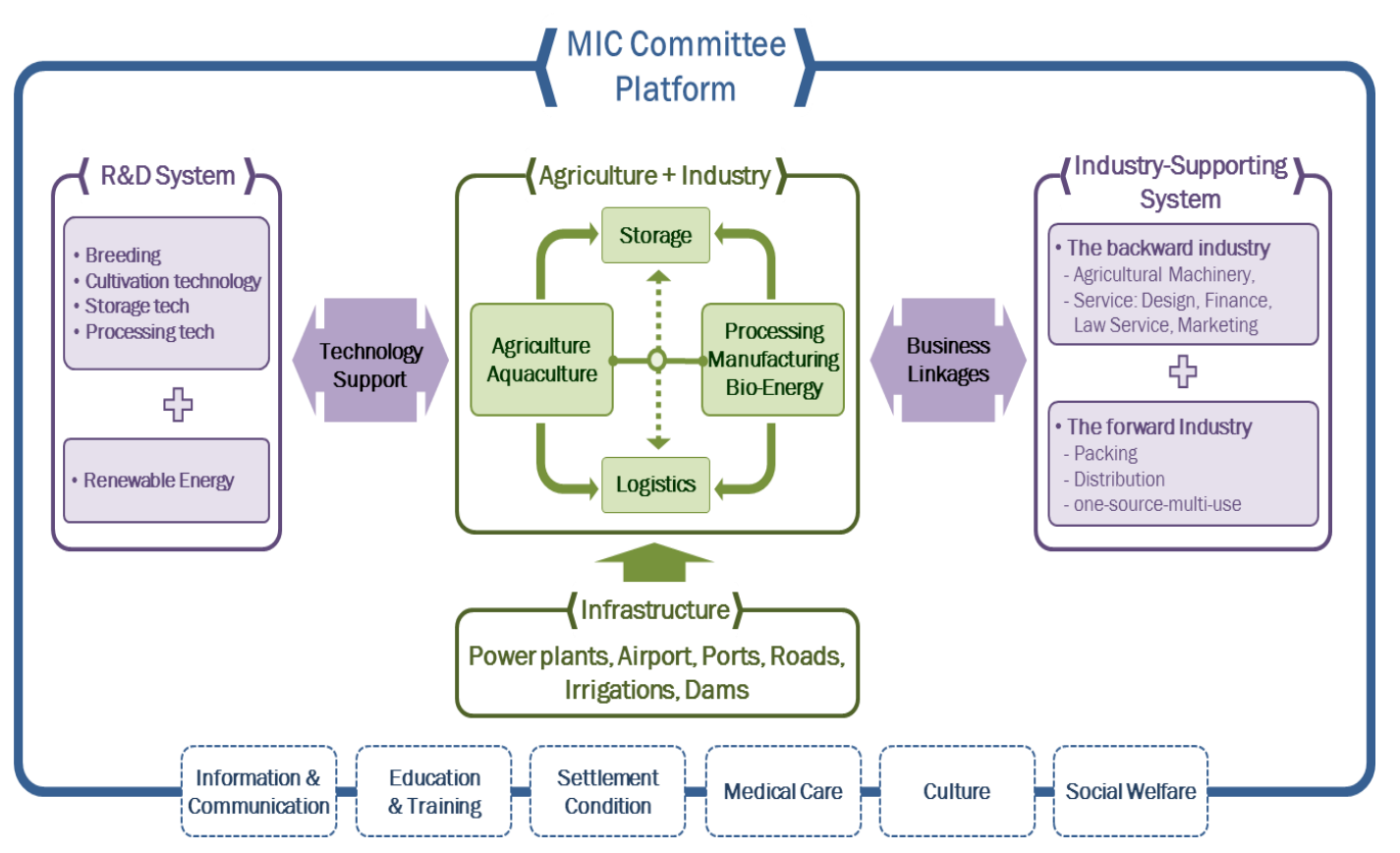

Figure 8. Elements of MIC 


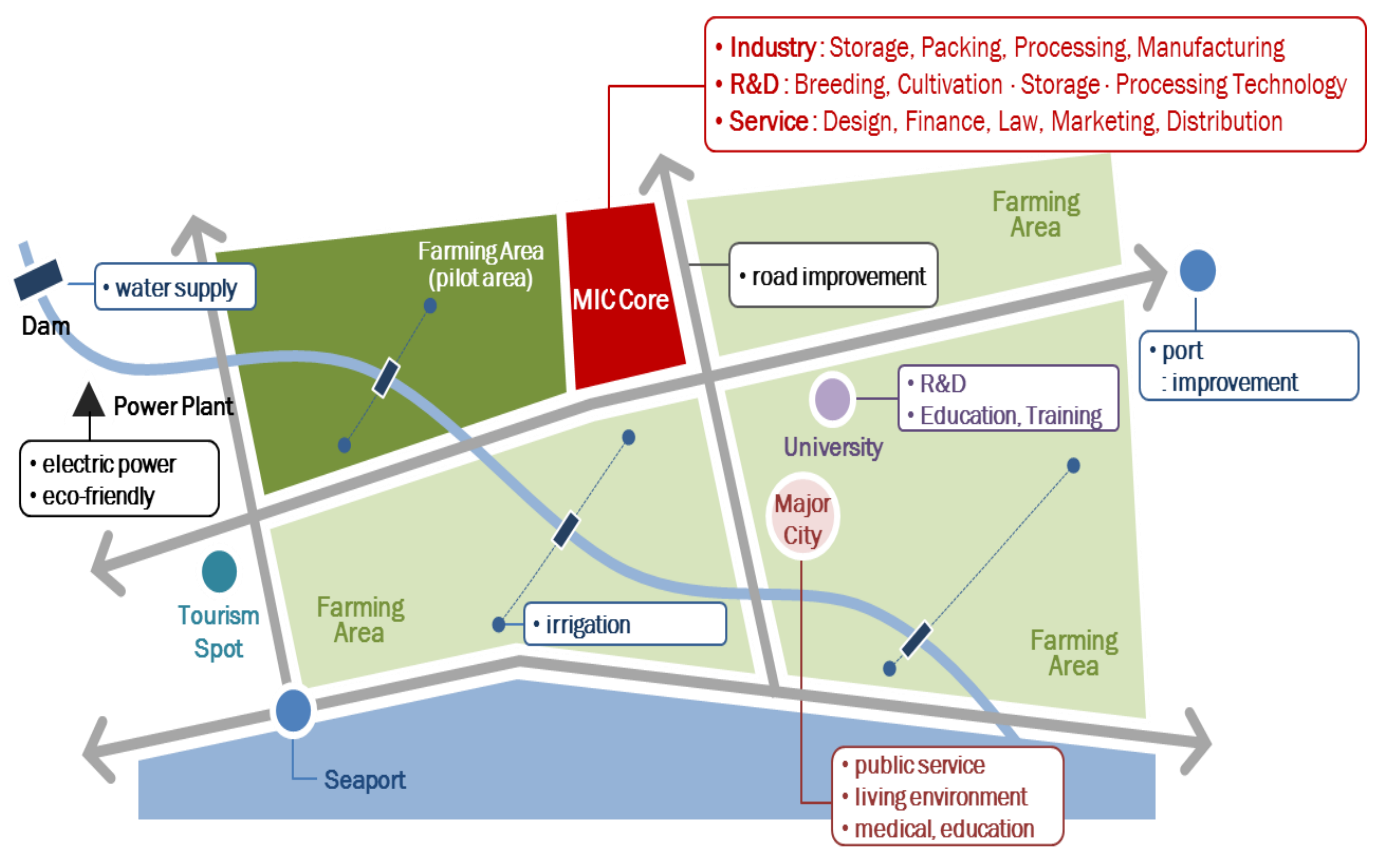

Figure 9. MIC Prototype

\subsection{Mutual Cooperation: Site Evaluation \& Selection for MIC}

This process is to examine and evaluate the proposed candidate sites for MIC and farming development initiative of the Philippines and also find the best places. The whole process consists of 4 steps; proposal of candidate site, selection of evaluation criteria, setup of evaluation sheet, set-up of evaluation model \& selection of the best places.

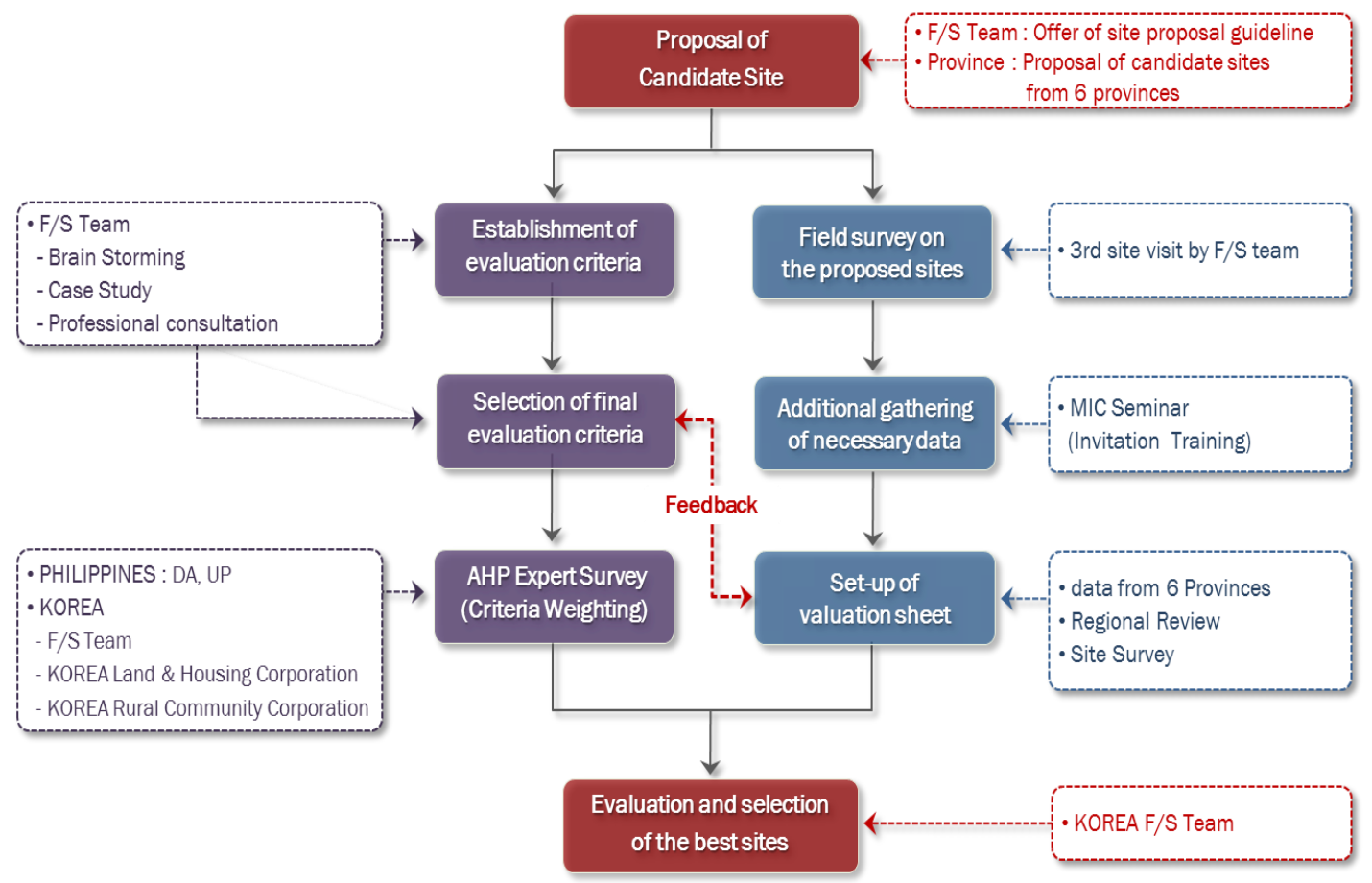

Figure 10. Site Evaluation and Selection Process 


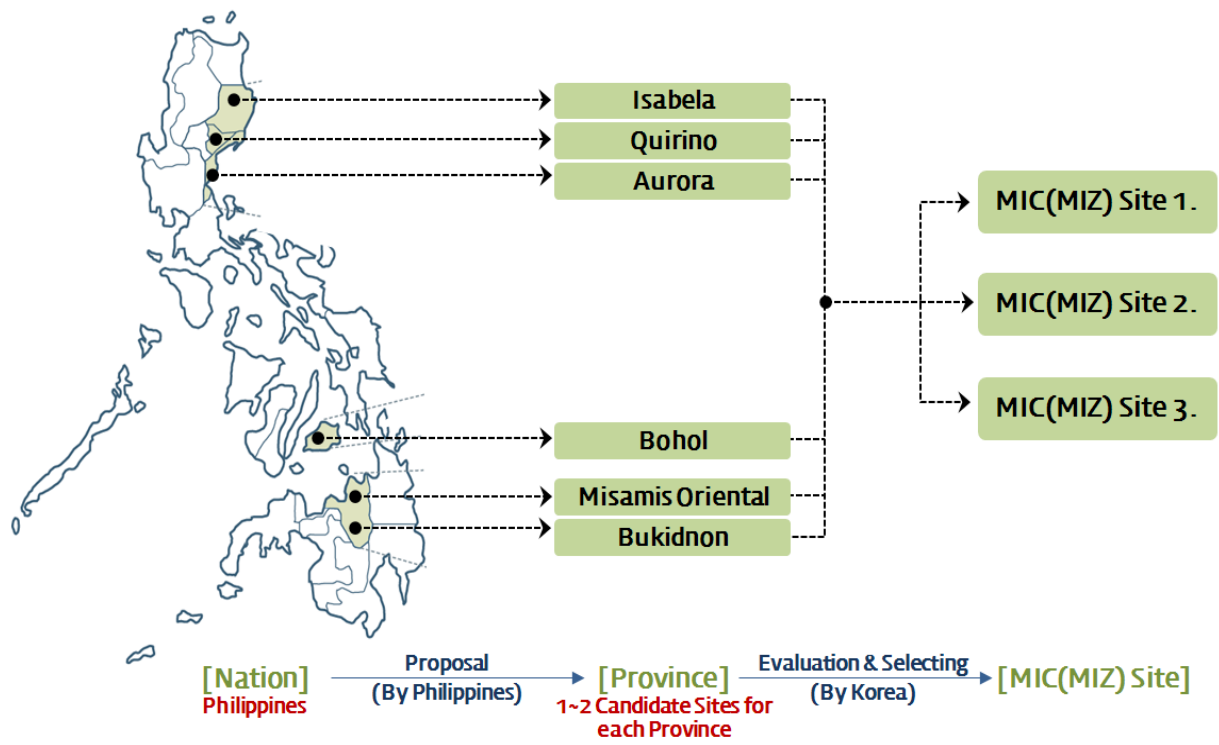

Figure 11. Philippine MIC Site Selection Process

At the site proposal step, candidate sites for MIC core were proposed by 6 provinces of the Philippines. In order to make consistent regional dataset of the proposed sites and the hinterland region, F/S team submitted site proposal guideline in advance and the local government of the Philippines gathered relevant regional data based on the guideline. In this step, mutual cooperation of all participants was essential. So F/S team visited DA and local provinces to enlighten their officials and it took several months.

At the selection of evaluation criteria step, criteria had been reviewed several times by professional discussion and consultation to select final evaluation criteria. Moreover AHP (Analytic Hierarchy Process) survey was performed by Korean and Philippine experts to determine the weight value of each evaluation criterion in an objective manner. Because it was obvious each criteria had different degree of significance in ranking the sites that the evaluation result could be distorted with no weight on the criteria.

Table 3. Weighting Result of Evaluation Criteria

\begin{tabular}{|c|c|c|c|c|c|c|c|c|}
\hline \multicolumn{2}{|c|}{ Categories } & \multicolumn{5}{|c|}{ Items } & \multirow{3}{*}{$\begin{array}{c}\text { Final } \\
\text { Weight }\end{array}$} & \multirow{3}{*}{ Rank } \\
\hline \multirow[b]{2}{*}{ Categories } & \multirow[b]{2}{*}{ Weight } & \multirow[b]{2}{*}{ Items } & \multirow[b]{2}{*}{ Weight } & \multicolumn{3}{|c|}{ Spatial range of evaluation } & & \\
\hline & & & & Province & $\begin{array}{c}\text { Farming } \\
\text { Area }\end{array}$ & $\begin{array}{l}\text { MIC } \\
\text { Core }\end{array}$ & & \\
\hline \multirow{9}{*}{$\begin{array}{l}\text { Locational } \\
\text { condition }\end{array}$} & \multirow{9}{*}{0.537} & Elevation of MIC site (Core \& farming) & 0.057 & & $\bullet$ & $\bullet$ & 0.031 & 16 \\
\hline & & Slope of MIC site (Core \& farming) & 0.120 & & $\bullet$ & $\bullet$ & 0.064 & 10 \\
\hline & & Availability of irrigation facilities & 0.118 & & $\bullet$ & & 0.063 & 11 \\
\hline & & Distance to airport from MIC site & 0.128 & & $\bullet$ & & 0.069 & 8 \\
\hline & & Distance to bulk carrier port from MIC & 0.092 & & & $\bullet$ & 0.049 & 14 \\
\hline & & Distance to container terminal from MIC & 0.121 & & & $\bullet$ & 0.065 & 9 \\
\hline & & Distance to major road from MIC site & 0.167 & & & $\bullet$ & 0.090 & 1 \\
\hline & & Distance to electric power network & 0.154 & & & $\bullet$ & 0.083 & 2 \\
\hline & & Distance to major city from MIC & 0.132 & & & $\bullet$ & 0.071 & 7 \\
\hline \multirow{7}{*}{$\begin{array}{l}\text { Socio- } \\
\text { economic } \\
\text { condition }\end{array}$} & \multirow{7}{*}{0.269} & Wage of agricultural employees & 0.168 & $\bullet$ & & & 0.045 & 15 \\
\hline & & Educational background & 0.053 & $\bullet$ & & & 0.014 & 18 \\
\hline & & Number of universities & 0.034 & $\bullet$ & & & 0.009 & 19 \\
\hline & & Ownership of proposed farming area & 0.071 & $\bullet$ & & & 0.019 & 17 \\
\hline & & Ownership of proposed MIC core site & 0.290 & & $\bullet$ & & 0.078 & 3 \\
\hline & & Average rental cost of farming area & 0.215 & & - & & 0.058 & 12 \\
\hline & & Submission of full data in time & 0.285 & & & $\bullet$ & 0.077 & 4 \\
\hline Agricultural & 0.194 & Frequency of typhoon damages & 0.367 & - & & & 0.071 & 6 \\
\hline
\end{tabular}




\begin{tabular}{c|l|l|c|c|c|c|c|c}
\hline \multirow{2}{*}{ condition } & Productivity of major crops & 0.371 & $\bullet$ & & & 0.072 & 5 \\
\cline { 3 - 8 } & & Capacity of irrigation facilities & 0.262 & $\bullet$ & & & 0.051 & 13 \\
\hline
\end{tabular}

At the step of establishment of evaluation sheet, F/S team visited both the proposed sites and the local government offices to develop the mutual understanding of the condition for the cluster development. The final evaluation sheet was built upon the regional data gathered by F/S team, the data submitted by 6 local governments of the Philippines on the site proposal process, and finally, the data from actual field survey by F/S team.

At the step of evaluation and selection of the best sites, the evaluation model of 5 scale classification was built based on the evaluation sheet and gathered regional data of the proposed sites. The evaluation process was followed by the selection of 3 final best sites for MIC development initiative.

\subsection{Governance and Investment: Strategic Plan for Execution}

Many related MIC players need to have distinguished roles to make the whole MIC task systematically so that it will be possible to achieve certain goals by each term. The roles of each player are summarized by terms below.

Table 4. Roles of MIC Player by Term

\begin{tabular}{|c|c|c|c|}
\hline Player & Short Term( 2015) & Mid Term(2015 2020) & $\begin{array}{c}\text { Long } \\
\text { Term }(2020 \sim 2025)\end{array}$ \\
\hline $\begin{array}{l}\text { Private } \\
\text { Invertor }\end{array}$ & $\begin{array}{l}\text { - Operation of a pilot } \\
\text { business at a smallest } \\
\text { scale }\end{array}$ & $\begin{array}{l}\text {-Participation in the local } \\
\text { farmer community } \\
\text {-Business localization }\end{array}$ & $\begin{array}{l}\text {-Introduction of the pilot } \\
\text { business to other areas }\end{array}$ \\
\hline $\begin{array}{c}\text { Local } \\
\text { Government }\end{array}$ & $\begin{array}{l}\text { - MIC promotion } \\
\text { group } \\
\text { - Investment on info- } \\
\text { service } \\
\text { Resettlement plan }\end{array}$ & $\begin{array}{l}\text {-Establishment of PR } \\
\text { center and regular public } \\
\text { meeting } \\
\text {-Securing an outstanding } \\
\text { workforce }\end{array}$ & $\begin{array}{l}\text {-Establishment of a local } \\
\text { institution in agriculture } \\
\text { to share know-how and } \\
\text { information }\end{array}$ \\
\hline $\begin{array}{c}\text { Central } \\
\text { Government }\end{array}$ & \begin{tabular}{l}
\multicolumn{3}{|c}{ - Attracting foreign aid } \\
for follow-up core \\
project \\
$-\quad$ Launching \\
Committee
\end{tabular} & $\begin{array}{l}\text {-Invest gov't and foreign } \\
\text { aid funds on priority } \\
\text { fields } \\
\text {-Establishment } \\
\text { integrated of } \\
\text { investment info system }\end{array}$ & $\begin{array}{l}\text {-Long-term support and } \\
\text { promotion programs }\end{array}$ \\
\hline
\end{tabular}

As local governments and inter-agencies of the central government are main players to implement MIC as well as attract investment as hosts, it is required to establish promotion entities from public organizations and set up a hierarchy framework to drive MIC-related policies and programs efficiently as shown below. 


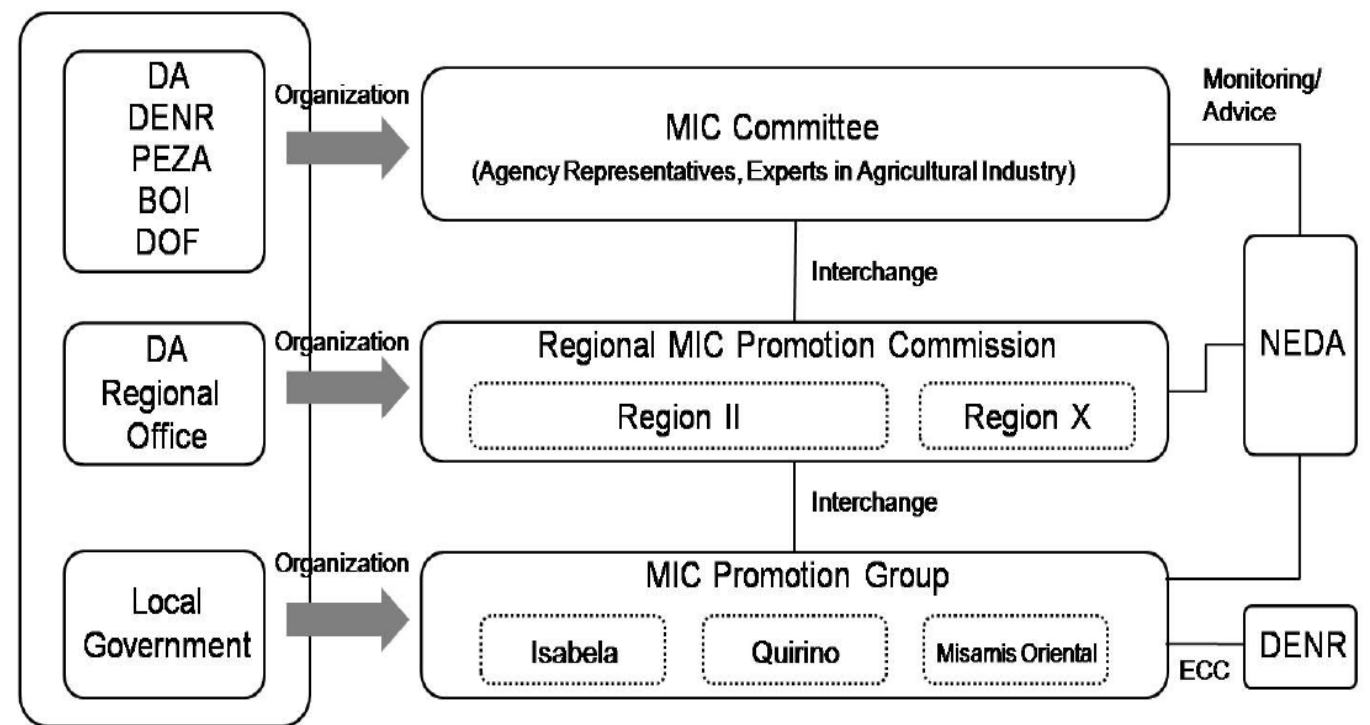

Figure 12. Policy Promotion System

Especially the 'MIC Promotion Group', which is an executive local organization, is important as it is a practical body directly supporting investors and deeply involved in contract matters. Followed by establishing the MIC promotion, the MIC promotion group and higher promotion entities need to find what project they have to promote and what funding (private and public) source they need to use in order to achieve early implementation of MIC.
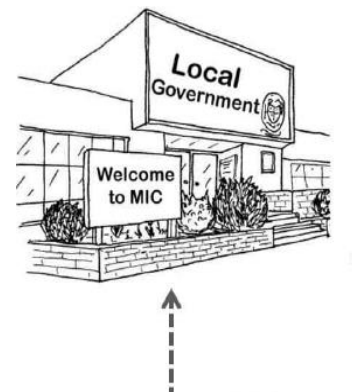

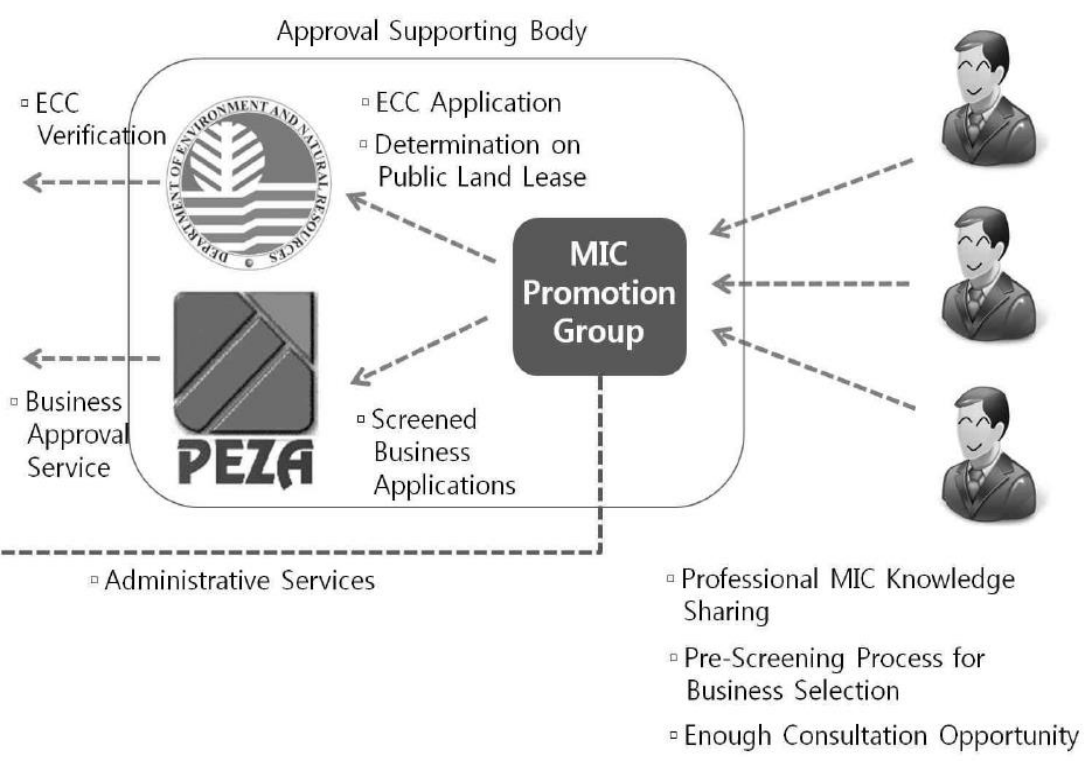

Figure 13. MIC Business Promotion Process with the New Proposed System

With the exception of the investment of the master developer, there is the necessity of investment from various ways such as ODA and governmental funding in many related fields in order to complete MIC Core. To attract the master developer securing hinterland farming area and prior funding for relevant infrastructure provision are essential. Therefore it is necessary for MIC promotion bodies to know potential funding sources for 
facilities that are planned on the master plan of MIC Core so that it is possible to prepare what the private sector needs by the public sector or two sectors approach jointly.

Table 5. Potential Funding Source for Prime Development Projects

\begin{tabular}{|c|c|c|c|c|c|}
\hline \multirow{2}{*}{ Categories } & \multirow{2}{*}{ Item } & \multirow{2}{*}{ Priority Facility } & \multicolumn{3}{|c|}{ Funding Source } \\
\hline & & & ODA & Public & Private \\
\hline \multirow{5}{*}{ MIC core } & Manufacturing & $\begin{array}{l}\text { Processing facility of corn, rice, } \\
\begin{array}{l}\text { livestock, fertilizer } \\
\text { agricultural machinery }\end{array}\end{array}$ & ○ & o & ○ \\
\hline & $\begin{array}{l}\text { Distribution \& } \\
\text { Storage }\end{array}$ & $\begin{array}{l}\text { Systematic product distribution } \\
\text { Space for corn, rice, high valued } \\
\text { fruits }\end{array}$ & O & O & O \\
\hline & $\mathrm{R} \& \mathrm{D}$ & $\begin{array}{l}\text { Agriculture science institution, Test } \\
\text { farm }\end{array}$ & O & o & - \\
\hline & Support & Education center \& Business center & 0 & 0 & - \\
\hline & Residence & Apartment, Hotel, Resort & - & - & O \\
\hline \multirow[b]{2}{*}{ Farming } & Agriculture & Demo Farm, Dairy Farm & 0 & O & - \\
\hline & Irrigation & $\begin{array}{lll}\begin{array}{l}\text { Irrigation } \\
\text { canal }\end{array} & \text { Reservoir, } & \text { Irrigation } \\
\end{array}$ & O & O & - \\
\hline \multirow[t]{2}{*}{ Infra } & Transportation & $\begin{array}{l}\text { Road construction, Access road to } \\
\text { MIC site }\end{array}$ & O & O & O \\
\hline & Energy & Renewable Energy Plant & o & O & O \\
\hline Etc. & Plan & Regional Development Plan & o & o & - \\
\hline
\end{tabular}

\section{The Outcome of MIC F/S Project}

After completing framework and preliminary feasibility study of MIC project, KoreaPhilippines EDCF consultative meeting and Korea-Philippines $\mathrm{PPP}^{1}$ forum under the auspices of the Korean government were held in manila, Philippines, in June, 2011. The meetings were evaluated that they became opportunities invigorating Philippines EDCF.

Especially, Korea-Philippines PPP forum was held for invigorating the entry of Korean companies to Philippines infrastructure projects. The Philippine government requested Korean companies to participate in road, railway, airport and water industry in the forum. Over 30 Korean companies which attended the forum had individual business meetings with project implementing agencies. The forum became a good chance to find business opportunity for the Korean companies which didn't have enough local information and network.

As Korea-Philippines win-win strategy found a shape like mentioned above, we regard that MIC project was successful. The project got linked to follow-up task as we expected.

\section{${ }^{1}$ PPP(Public-Private Partnership)}

A government service or private business venture which is funded and operated through a partnership of government and one or more private sector companies. Private sector companies raise fund for project and government guarantee their operations. 


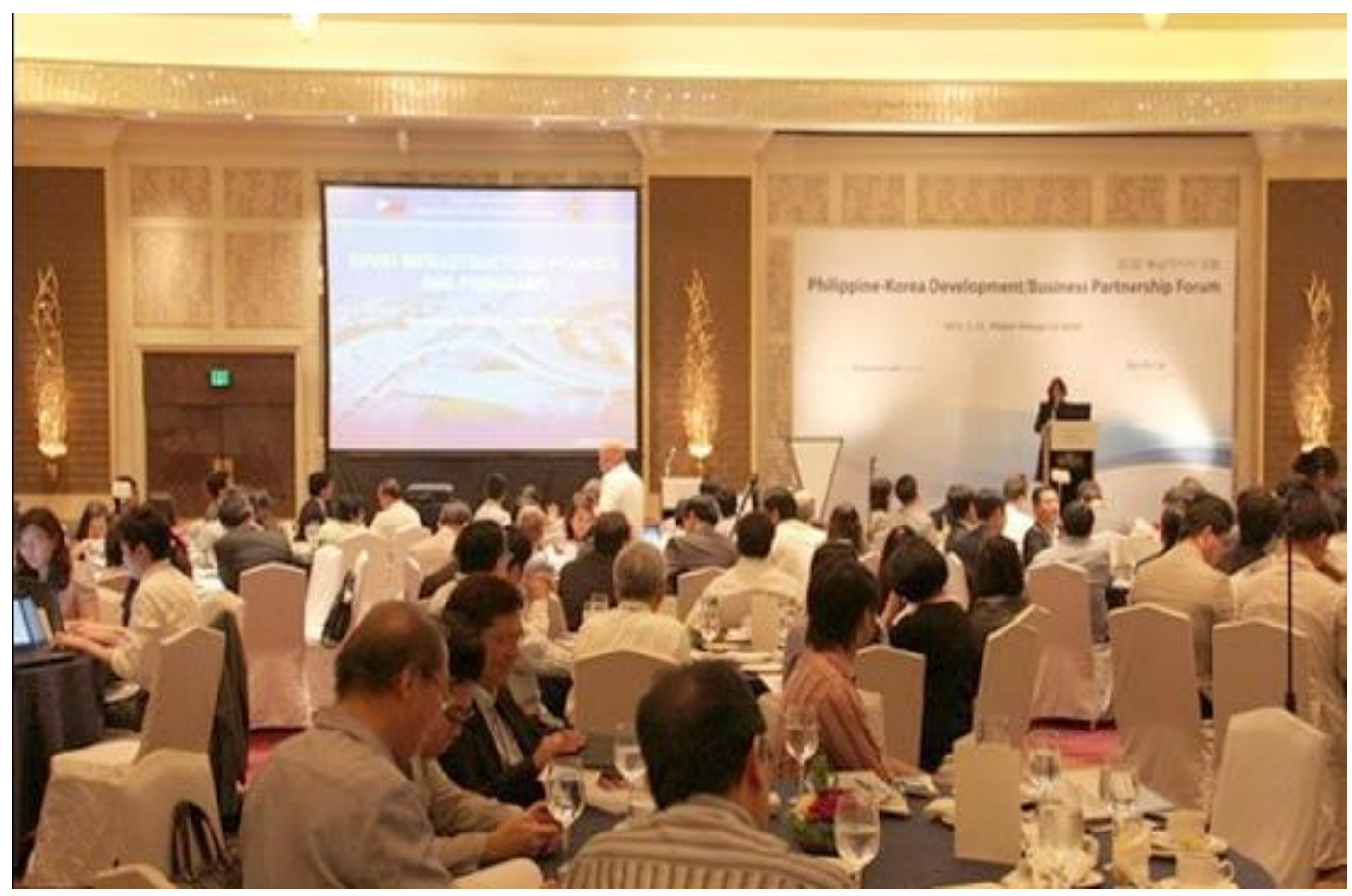

\section{Conclusion}

The population of Korea reached 50 million in June, 2012. The countries which had over $\$ 20,000$ GDP per capita and 50 million populations were only US, Japan, Germany, UK and Italy before Korea had them.

Unlike the impressive figures, there are lots of difficulties in our industries. Some manufacturing industries are reorganized to high value added businesses but some are dying as conventional industries. It is natural that industrial structure changes in the process of economic development, but it is sorry to leave existing facilities and know-how behind.

Developing countries are vast markets which need such land development know-how and existing manufacturing facilities and technologies. Korean low technologies can create infinite value in developing countries. Globalization and economic development of China for last 10 years are expediting economic development of many developing countries with the ASEAN as the center. The institute of ADB is forecasting that investment for infrastructure projects will reach $\$ 41$ trillion in the world, especially, $\$ 8$ trillion in Asian market.

International development cooperation project is an important item for entering such vast market. Development cooperation for industrial complex as a symbol of economic development of Korea can enter the market and it can be linked with energy, logistics, information infra and housing construction. The experiences through the international development cooperation project mentioned in this study have a great implication to us.

The implication of this study shows the model of win-win strategy for both recipient country and donor country in international development cooperation with presentation of packaged strategic approach from the establishment of regional plan to the establishment of specific plan for project area. It could be benchmarked as a successful case in international development cooperation, presenting the project model which private investment cooperation could be made in international development cooperation through the establishment of specific implementation strategy after master plan. 
International Journal of Transportation

Vol.3, No.1 (2015) 